\title{
Proses Pembentukan Konsep dalam Menemukan Kembali Teorema Pythagoras dan Miskonsepsi yang Terjadi dengan Pendekatan Pendidikan Matematika Realistik Indonesia (PMRI)
}

\author{
Fauzi Mulyatna \\ Universitas Indraprasta PGRI \\ fauzi.mulyatna@unindra.ac.id
}

\begin{tabular}{l}
\hline \hline Article Info \\
\hline Article history: \\
Received Mar $4^{\text {th }}, 2019$ \\
Revised Mar $25^{\text {th }}, 2019$ \\
Accepted April $11^{\text {th }}, 2019$ \\
\hline
\end{tabular}

Keywords:

Misconceptions;

Pythagorean Theorem;

PMRI

This research aims to find out the process of concept formation in reinventing Pythagorean Theorem and to analyze the result of that process and the misconceptions that may emerge. The type of this research is qualitative research which is analyzed descriptively. This research applies class setting method in learning activity with the implementation of PMRI approach and it focuses on two subjects. The results shows that the process of concept formation in reinventing the Pythagorean Theorem with PMRI approach can work well. However, the two subjects have not been able to construct the given problem, which is in the form of a question, to be the form of a mathematical modeling. Subject 1 still processes the information rawly. Therefore, the result of concept finding with his/her knowledge used for solving problems by the same model has not been able to reduce data. Subject 2 has been able to process the obtained information and he/she can interpret the problem further. However, both subjects still experience misconceptions not only in their already possessed knowledge but also their newly acquired knowledge. Those misconceptions are misconception in calculating operation of equation system, which should be calculating operation on both segments but it is only carried out in one segment, misconception in describing hypotenuse and misconception in naming edges of a right triangle.

Kata Kunci:

Abstrak

Miskonsepsi;

Penelitian ini untuk mengetahui proses pembentukan 
2 | Mulyatna: Proses Pembentukan Konsep dalam Menemukan Kembali Teorema Pythagoras... Teorema Pythagoras;
PMRI konsep dalam menemukan kembali Teorema Pythagoras dan menganalisis hasil dari proses tersebut dan miskonsepsi yang mungkin timbul. Jenis penelitian ini adalah penelitian kualitatif. yang dianalisis secara deskriptif. Penelitian ini menggunakan setting kelas dalam kegiatan pembelajaran dengan implementasi pendekatan PMRI dan fokus pada 2 subyek. Hasil penelitian menunjukkan proses pembentukan konsep dalam menemukan kembali Teorema Pythagoras dengan pendekatan PMRI dapat berjalan dengan baik, tetapi kedua subyek belum mampu mengkonstruksikan permasalahan yang diberikan berupa soal menjadi bentuk pemodelan matematika. Subyek 1 mengolah informasi secara mentah. Hasil dari penemuan konsep dengan pengetahuannya digunakan dalam memecahkan masalah dengan jalan yang sama, belum mampu mereduksi data. Subyek 2 sudah mampu mengolah informasi yang diperolah dan menafsirkan masalah secara lebih jauh. Kedua subyek masih mengalami miskonsepsi, baik itu pengetahuan yang telah dimiliki maupun pengetahuan yang baru didapat. Miskonsepsi dalam operasi hitung pada sistem persamaan, yaitu operasi hitung yang seharusnya pada kedua ruas, yang dilakukan hanya pada satu ruas saja, miskonsepsi dalam mendeskripsikan sisi hipotenusa sebagai sisi yang miring dan pemberian nama sisi-sisi dari segitiga siku-siku.

\section{PENDAHULUAN}

Proses yang dilalui siswa dalam transformasi pengetahuan baru meliputi kegiatan belajar dan pembelajaran. Di sisi lain ada peran yang dilakukan guru, yaitu mengajar. Mengajar merupakan kegiatan atau perlakuan profesional yang diberikan oleh guru. Siswa kemudian melakukan kegiatan atau upaya merespon pembentukan pengetahuan baru yang diberikan oleh guru sebagai proses belajar. Sedangkan kedua kegiatan membutuhkan pertautan yang menyeluruh untuk terjadinya interaksi belajar-mengajar sebagai proses pembelajaran. Dalam pembelajaran melibatkan proses yang kompleks dan berbagai aspek yang saling berkaitan. Sehingga diperlukan suatu rencana dan desain pembelajaran yang tepat. 
Hal ini sejalan dalam penelitian Kirom (2017) Guru dan siswa merupakan faktor penentu yang sangat dominan dalam pendidikan umumnya, karena guru dan peserta didik memegang peranan dalam proses pembelajaran, di mana proses pembelajaran merupakan inti dari proses pendidikan secara keseluruhan yang bertujuan terjadinya perubahan tingkah laku anak.

Dalam kegiatan belajar, siswa sering dihadapkan pada masalah yang harus dipecahkan, khususnya menyelesaikan soal-soal. Pada mata pelajaran matematika, umumnya siswa dihadapkan untuk menyelesaikan soal dan mencari pemecahannya dengan teliti, teratur dan tepat sehingga diperoleh prestasi belajar matematika yang tinggi. Wardono (2016) memberikan gambaran, pembelajaran matematika di sekolah tidak selalu menekankan kepada siswa agar dapat meningkatkan kemampuan berpikir logis, analitis, sistematis, kritis, dan kreatif, tetapi tetap fokus pada buku teks. Hal ini menegaskan, kegiatan pembelajaran masih cenderung terfokus pada buku teks.

Ada hal penting yang harus dilakukan oleh guru dalam meningkatkan prestasi matematika siswa, di antaranya adalah memberikan kesempatan belajar kepada siswa secara langsung dan sesuai kemampuannya, fokuskan kepada pelajaran matematika yang bermakna di kehidupan, berikan kesempatan kepada siswa untuk melakukan praktik dan menemukan sendiri, perbaiki prasyaratnya, gunakan metode kelompok kecil dalam proses pembelajaran dan memulailah sesuatu dari hal yang sifatnya konkrit. Seperti halnya pendapat Habsah (2017), learning mathematics should begin with an introduction to the situation (contextual problem). Inilah yang sering kali dilupakan oleh guru dengan berbagai alasan. Padahal salah satu saja tidak diperhatikan, maka akan timbul permasalahan. Kesempatan yang diberikan kepada siswa untuk melakukan praktik dan menemukan sendiri sering kali tidak diakomodasi guru dalam pembelajaran di kelas. Sehingga proses pembentukan konsep hanya akan sebatas hafalan.

Proses yang hanya sebatas hafalan akan menjadi penyebab siswa tidak mampu menerapkan konsep matematika dengan baik. Hal ini 
4 | Mulyatna: Proses Pembentukan Konsep dalam Menemukan Kembali Teorema Pythagoras...

merujuk dalam penelitiannya Novak (2002) bahwa belajar dengan cara menghafal tidak efektif dalam membentuk struktur kognitif, sehingga dapat memunculkan adanya miskonsepsi.

Hasil wawancara dengan guru matematika menunjukkan bahwa siswa belum mampu menggunakan konsep dalam menemukan solusi dari berbagai permasalahan yang bervariasi. Oleh karena itu siswa perlu memiliki pengalaman yang bervariasi untuk menemukan solusi dari permasalahan yang diberikan sehingga membentuk konsep yang kuat. Dalam pembelajaran matematika, sebenarnya guru seringkali sudah menekankan kepada siswa-siswinya akan pentingnya memahami suatu konsep.

Namun, sebagian guru masih saja ada yang mengejar ketepatan alokasi waktu terhadap materi yang disampaikan. Siswa kemudian dihadapkan pada situasi belum memahami dengan baik konsep dalam matematika. Guru pada kondisi tertentu hanya menekankan pada rumus jadi yang siap pakai. Kemudian siswa menganggap rumus-rumus, yang seakan-akan datang secara tiba-tiba dengan segala keajaiban dan kerumitannya, itu merupakan konsep. Pada dasarnya, dalam pembelajaran matematika dikenal 4 hal yaitu fakta, konsep, prinsip, dan keterampilan. Seringkali, guru mencampuradukkan empat hal tersebut. Padahal keempatnya berbeda dan memiliki karakteristik pembelajaran yang berbeda pula. Pada penelitian ini tidak membahas secara umum dari keempat hal tersebut, tetapi lebih khusus pada pemahaman konsep dan implikasi yang ada dari kesalahan siswa dalam menerima, memahami dan membentuk konsep itu sendiri, yaitu miskonsepsi.

Kegiatan pembelajaran yang baik adalah melibatkan siswa aktif untuk menemukan dan mengkontruksi konsep yang menjadi tujuan pembelajaran. Aktivitas nyata dilakukan langsung oleh siswa dengan bimbingan dari guru. Tetapi berdasarkan observasi awal yang dilakukan, siswa hanya mendapat porsi yang sangat sedikit dalam mengkonstruksi pembentukan pengetahuan. Siswa hanya sebagai obyek yang terkesan dianggap belum memiliki pengetahuan dan tidak diajak untuk terlibat dalam menemukan solusi ataupun formula untuk memecahkan masalah. 
Hal ini terlihat saat peneliti ikut dalam proses pembelajaran dan mengamati secara langsung kegiatan siswa kelas VIII ${ }^{\mathrm{A}}$ SMP Negeri 3 Karang Pandan. Untuk itu peneliti bermaksud mengimplementasikan Pendekatan PMRI di kelas VIII ${ }^{\mathrm{A}}$ SMP Negeri 3 Karang Pandan sebagai bagian dari proses pembentukan konsep dalam menemukan kembali Teorema Pythagoras. Sebagai langkah awal, pastilah terdapat kendala yang muncul dalam implementasi Pendekatan PMRI tersebut, sehingga peneliti sekaligus bermaksud menganalisis kemungkinan miskonsepsi yang terjadi sebagai implikasi dari pembentukan konsep yang terjadi.

Dorongan untuk melakukan penelitian tentang miskonsepsi juga diperkuat berdasarkan hasil penelitian Tekkaya (2002) bahwa sebelum dapat diperbaiki, miskonsepsi perlu diidentifikasi. Proses identifikasi miskonsepsi diperlukan untuk mengembangkan strategi yang dapat memberikan siswa pengetahuan dengan konseptual yang akurat. Jika miskonsepsi tidak terdeteksi dan segera diperbaiki, miskonsepsi akan membawa dampak negatif pada pembelajaran yang selanjutnya. Sejalan dengan hasil tersebut, menurut Hamza dan Wickman (2007) sebagian besar pendorong penelitian tentang miskonsepsi siswa adalah kekhawatiran bahwa miskonsepsi mengganggu inti pokok ilmu pengetahuan yang dimaksudkan dan karena itu miskonsepsi perlu diatasi.

\section{METODE PENELITIAN}

Jenis penelitian ini adalah penelitian kualitatif deskriptif dengan setting kelas dalam kegiatan pembelajaran dengan implementasi pedekatan PMRI. Impelementasi pendekatan PMRI dilakukan di kelas VIII ${ }^{A}$ SMP Negeri 3 Karang Pandan, Kabupaten Karanganyar. Subyek dalam penelitian ini adalah siswa kelas VIII $^{\mathrm{A}}$ SMP Negeri 3 Karang Pandan, tahun pelajaran 2018/2019 yang difokuskan pada 2 (dua) orang siswa dengan kriteria dalam penemuan kembali Teorema Pythagoras mempunyai cara yang berbeda. Dalam pembelajaran, peneliti benar-benar mengikuti dan mengamati proses diskusi, sehingga dapat mengindentifikasi dengan segera, proses penemuan Teorema Pythagoras 
6 | Mulyatna: Proses Pembentukan Konsep dalam Menemukan Kembali Teorema Pythagoras...

dengan cara yang berbeda. Dengan bantuan guru, peneliti juga mendapatkan subjek yang aktif dalam diskusi.

Obyek penelitiannya yaitu keseluruhan proses dan hasil pembelajaran matematika dalam upaya penemuan kembali Teorema Pythagoras dan analisis dari miskonsepsi yang mungkin terjadi. Data penelitian ini berupa analisis hasil observasi dengan bantuan lembar observasi, hasil analisis pekerjaan siswa dalam mengerjakan tes diagnostik dan hasil analisis dari wawancara yang kemudian disajikan dalam bentuk tulisan (script). Data awal yang diperoleh melalui analisis proses pembelajaran berbantuan lembar observasi untuk mengetahui implementasi pendekatan PMRI. Selanjutnya peneliti melakukan analisis terhadap hasil pekerjaaan subyek dalam tes diagnostik untuk mengetahui penerapan penemuan kembali konsep teorema Pythagoras dan miskonsepsi yang mungkin terjadi pada masing-masing soal.

Hasil analisis jawaban tertulis subyek kemudian menjadi acuan dalam melakukan wawancara. Wawancara dimaksudkan untuk memperdalam informasi yang belum jelas dalam lembar jawaban subyek. Teknik analisis data yang dilakukan melalui reduksi data, display data, mengambil kesimpulan dan verifikasi. Reduksi data merupakan pemilihan data-data yang mendukung fokus dalam penelitian, yang merupakan setiap bagian dari analisis data. Proses penyajian hasil penemuan kembali Teorema Pythagoras dan jawaban tertulis subjek dalam tes diagnostik merupakan display data dalam penelitian ini. Kesimpulan dan verifikasi merupakan hasil dari keseluruhan analisis. Triangulasi dalam validasi data penelitian adalah dengan teknik yang berbeda untuk memperoleh data yang sama, yaitu dengan teknik observasi, tes diagnostik dan teknik wawancara.

\section{HASIL PENELITIAN DAN PEMBAHASAN Implementasi Pendekatan PMRI}

Peneliti mengawali proses pembelajaran menyampaikan judul materi, tujuan pembelajaran dan menginformasikan secara singkat 
kegiatan pembelajaran yang akan dilakukan siswa serta menyampaikan pembelajaran akan dilakukan dengan imlementasi pendekatan PMRI.

Pada inti pembelajaran, peneliti membagi siswa dalam kelompokkelompok yang beranggotakan tiap kelompok 3-4 siswa. Untuk memulai diskusi, peneliti menunjukkan sebuah alat peraga. Kemudian peneliti menyakan kepada siswa, alat peraga yang dibawa tadi berupa bangun apa. Siswa bersaut-sautan menjawab. Peneliti menegur, dan menyampaikan etika untuk menyampaikan pendapat. Hal ini perlu untuk pembiasaan bagi siswa. Salah satu siswa menjawab, bahwa alat peraga yang dibawa tersebut merupakan segitiga siku-siku dengan menyebutkan ciri-cirinya yaitu tepat satu sudutnya besarnya $90^{\circ}$. Peneliti menyampaikan bahwa ada sebuah teorema tentang segitiga siku-siku tanpa menyebutkan detailnya. Berdasarkan prinsip dari pendekatan PMRI, maka proses pembelajaran selanjutnya akan berlangsung dalam 3 tahapan. Guided Re-Invention merupakan tahapan penemuan kembali secara terbimbing. Pada kegiatan ini, siswa diberikan LKS (Lembar Kegiatan Siswa) untuk mengkonstruksikan pengetahuan yang dimiliki sebelumnya dalam proses menemukan kembali Teorema Pythagoras. Didactical Phenomenology atau fenomena didaktik menggunakan masalah kontekstual, dalam LKS terdapat kegiatan yang dapat dilakukan siswa dalam rangka mengkonstruksi pengetahuan yang ada dan membentuk pengetahuan yang baru. Yang terakhir adalah Self Develop Model atau membangun sendiri model. Dalam LKS disediakan kertas berpetak yang berguna untuk mengkonstruksikan sisi-sisi segitiga siku-siku. Dengan harapan bahwa siswa telah memiliki pengetahuan lama, kemudian dapat dikonstruksikan ke dalam pengetahuan baru sehingga dapat membentuk pengetahuan baru yaitu Teorema Pythagoras. Kemudian pengetahuan baru yang didapat yaitu Teorema Pythagoras digunakan untuk menyelesaikan permasalahan nyata yang dapat ditemui dalam kehidupan sehari-hari.

\section{Analisis Implementasi Pendekatan PMRI}

Implementasi pendekatan PMRI dalam proses pembelajaran yaitu siswa diberikan kesempatan untuk berdiskusi dalam kelompoknya. 
8 | Mulyatna: Proses Pembentukan Konsep dalam Menemukan Kembali Teorema Pythagoras...

Diskusi dalam kelompok yaitu mengacu pada LKS yang diberikan oleh peneliti. Peneliti memberikan kebebasan kepada siswa untuk mengkonstruksikan pengetahuan barunya. Peran peneliti dalam pelaksanaan diskusi adalah memberikan bimbingan, tetapi yang menjadi acuan adalah tetap pada keaktifan siswa. Dari dua subyek dalam penelitian ini memberikan penjelasan yang berbeda dalam menemukan kembali teorema Pythagoras.

Temuan analisis aktivitas subyek 1. Setelah berdiskusi dengan kelompoknya, subyek 1 mempresentasikan hasil diskusi, hasilnya adalah membentuk persegi dari kertas berpetak seperti tampak dalam gambar.

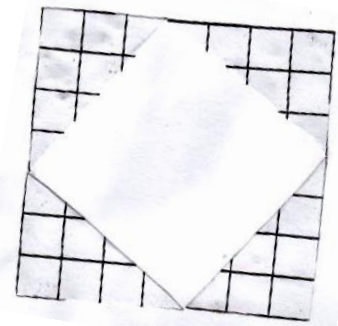

\section{Gambar 1 Persegi dari Kertas Berpetak}

Penjelasan dari subyek 1 adalah berdasarkan diskusi, subyek 1 langsung mengkonstrusikan 4 buah segitiga siku-siku dengan sisi-sisi siku-sikunya yang panjangnya masing-masing 3 satuan dan 4 satuan. Ternyata setelah diukur, panjang sisi miringnya 5 satuan. Kemudian subyek 1 menjelaskan, terlihat dalam gambar bahwa luas persegi besar dapat ditemukan dengan menambahkan persegi kecil dengan luas empat kali segitiga siku-siku. Dalam hal ini, subyek 1 telah memiliki pengetahuan tentang luas persegi dan luas segitiga siku-siku. Kemudian subyek 1 menamai masing-masing sisi segitiga siku-siku dengan $a, b$ dan $c$ dengan sisi miringnya $c$. Sehingga sisi persegi kecil memiliki panjang $c$ satuan dan sisi persegi yang besar memiliki panjang $(a+b)$ satuan. Subyek 1 menjelaskan bahwa dari hasil perhitungan yang didapat,

Luas persegi besar $=$ Luas persegi kecil $+(4 \times$ Luas segitiga $)$

Secara lengkap, berikut ini yang dituliskan oleh subyek 1: 


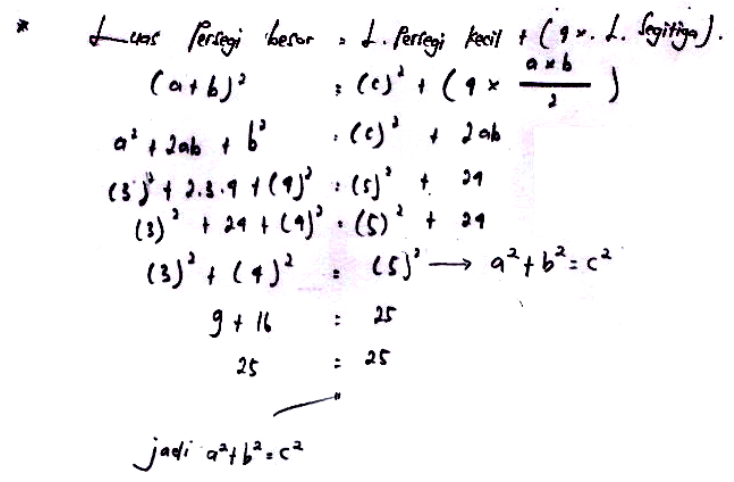

\section{Gambar 2 Hasil Diskusi dari Subyek 1 dalam Menemukan Kembali Teorema Pythagoras}

Subyek 1 berdasarkan diskusi dalam kelompoknya kemudian menyimpulkan bahwa: $a^{2}+b^{2}=c^{2}$.

Begitu juga dilakukan analisis terhadap aktivitas subyek 2. Sama halnya dengan subyek 1 , subyek 2 juga mempresentasikan hasil diskusi dengan kelompoknya. Berbeda dengan subyek 1, subyek 2 mengkonstruksikan pengetahuan dan konsepnya tentang Teorema Pythagoras dengan membuat persegi dengan sisinya merupakan panjang dari sisi-sisi segitiga. Berikut ini hasil dari diskusi subyek 2 dengan kelompoknya membentuk segitiga siku-siku dengan 3 sisi persegi dari kertas berpetak.

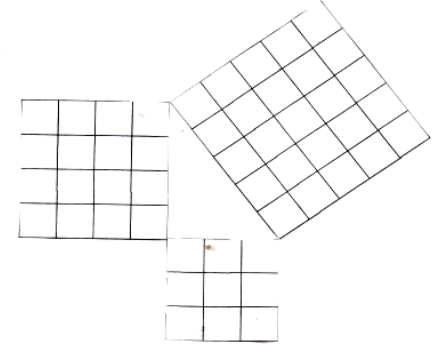

Gambar 3. Segitiga Siku-Siku dengan 3 Sisi Persegi dari Kertas Berpetak 
10 | Mulyatna: Proses Pembentukan Konsep dalam Menemukan Kembali Teorema Pythagoras...

Kemudian subyek 2 mempresentasikannya di depan kelas. Subyek 2 pertama-tama hanya menunjukan 3 buah persegi dari kertas berpetak. Dia memanggil teman dari kelompok lain (dengan inisial KAAS) untuk ikut maju ke depan. Kemudian dia meminta teman yang maju tadi untuk mulai merangkai 3 buah persegi menjadi segitiga. Menjadi menarik proses presentasi dengan ikut melibatkan anggota di luar kelompok subyek 2 . Subyek 2 kemudian menanyakan segitiga apa yang terbentuk, kemudian KAAS menjawab segitiga siku-siku. Dilanjutkan subyek 2 memandu KAAS untuk menutupi seluruh permukaan persegi yang paling besar dengan dua persegi yang lain. Dan ternyata tepat dapat tertutupi semua. Subyek 2 kemudian mengajak diskusi teman yang lain, dan menanyakan berapa luas masing-masing persegi. Subyek 2 memberikan penjelasan bahwa dengan cara menutupi persegi yang besar dengan dua persegi yang lain itu menunjukan bahwa jika kedua persegi digabung akan menghasilkan persegi yang besar. Ternyata luas dari jumlah persegi sama dengan luas persegi yang besar. Dan masing-masing sisi persegi merupakan sisi-sisi dari segitiga siku-siku juga. Kemudian subyek 2 langsung menuliskan $a^{2}+b^{2}=c^{2}$ di papan tulis.

Dari proses pembelajaran yang telah berlangsung, dapat diperoleh data dari masing-masing subyek. Implementasi pendekatan PMRI mampu merangsang siswa untuk aktif dalam pembelajaran serta mampu memberikan ruang bagi siswa untuk menggali pengetahuannya. Siswa mampu beradaptasi dengan pembelajaran yang mengimplementasikan pendekatan PMRI. Hal ini dapat dilihat dari proses diskusi yang berjalan baik. Siswa tidak ragu-ragu mengemukakan pendapat dan gagasannya. Untuk memperoleh konsep yang sama, ternyata siswa mampu berpikir dengan jalan yang berbeda. Ini akan menyadarkan siswa bahwa matematika tidak harus sama persis dalam hal proses. Proses berbeda diperbolehkan, tetapi harus dengan dasar konsep yang benar. Kedua subyek mampu mengkonstruksi pengetahuannya untuk memperoleh konsep tentang Teorema Pythagoras.

Pada tahap menuju pada tingkatan yang lebih formal, ternyata siswa belum mampu memberikan proses yang sempurna. Kedua subyek 
langsung

tertuju

pada

$a^{2}+b^{2}=c^{2}$, yang mereka anggap itu sebagai Teorema Pythagoras.

\section{Analisis Hasil dari Pekerjaan Subyek}

Untuk mengetahui proses pembentukan konsep itu benar-benar tidak hanya sebatas bisa menuliskan, bisa menemukan tetapi mamahami untuk mengaplikasikannya dalam pemecahan masalah, maka subyek diberikan permasalahan yang berupa tes diagnostik. Tes ini dikerjakan secara individu.

Tes diagnostik ini berbentuk uraian, dengan masalah yang disajikan merupakan permasalahan yang dapat ditemukan dalam dunia nyata. Ini berarti masalah telah disajikan dalam bentuk masalah kontekstual/realistik. Kemudian subyek diharapkan mampu mengkonstruksi pengetahuan yang dimiliki untuk menyelesaikan permasalahan yang disajikan. Siswa dapat mengolah informasi dari persoalan yang diberikan, kemudian mengubahnya ke dalam bentuk matematika, dan menyelesaikannya dengan konsep yang telah dimilikinya.

Hasil pekerjaan dari masing-masing subyek kemudian dianalisis. Berikut ini hasil dari pekerjaan subyek 1.

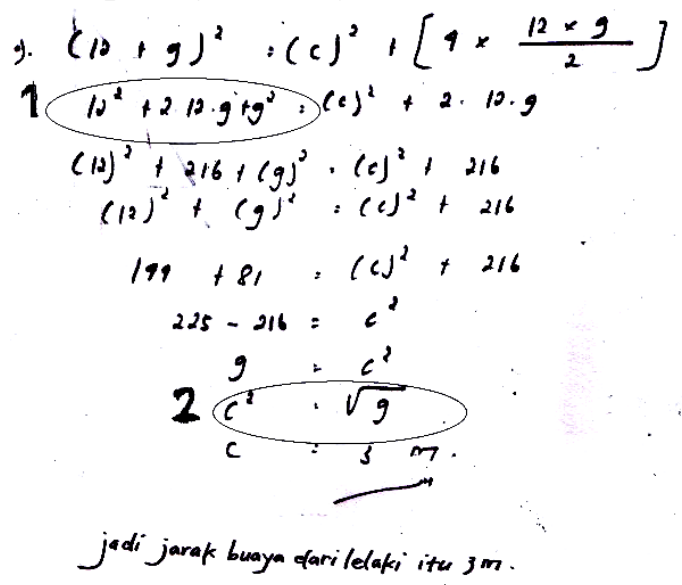

Gambar 4. Hasil Pekerjaan dari Subyek 1 
Tampak bahwa subyek 1 belum mampu untuk mengolah apa yang ditemukannya tentang Teorema Pythagoras. Subyek 1 mengerjakan langsung tertuju pada hitungannya, tanpa menelaah dahulu yang diketahui dalam soal dan mengkonstruksi yang ingin diselesaikan dalam soal. Subyek 1 tidak berusaha mengkonstruksikan permasalahan dalam bentuk ilustrasi gambar. Sehingga tidak tampak apa yang dimaksud dengan huruf c.

Ternyata proses yang dilalui subyek 1, mengerjakan soal dengan menirukan apa yang telah ditemukannya dalam pembuktian Teorema Pythagoras. Subyek 1 kembali pada proses bahwa menyelesaikan permasalahan dimulai dari pembentukan persegi besar yang kemudian ditunjukkan luas persegi besar sama dengan luas persegi kecil dan empat segitiga siku-siku yang menyusunnya. Hal ini membuktikan bahwa sebenarnya subyek 1 belum mampu untuk mengolah informasi dari apa yang ditemukannya. Berarti subyek 1 belum mampu untuk menemukan konsep dalam Teorema Pythagoras. Ini berarti subyek 1 salah konsep.

Dari Gambar 4, subyek 1 tampak juga mengalami miskonsepsi dalam "menghilangkan" angka 216. Peneliti menduga, subyek 1 hanya sebatas berdasarkan pengalamannya dalam menemukan Teorema Pythagoras, bahwa sisi kiri merupakan bentuk dua bilangan yang masingmasing dikuadratkan. Hal ini dapat dilihat dari Gambar 4 pada lingkaran 1.

Subyek 1 juga mengalami miskonsepsi dalam operasi hitung untuk mencari akar dari suatu bilangan yang sebelumnya merupakan hasil dari kuadrat bilangan. Hal ini bisa dilihat dari gambar 4 pada lingkaran 2 . Ruas kanan sudah dalam bentuk $\sqrt{9}$ tetapi ruas kiri masih dalam bentuk $c^{2}$.

Selanjutnya hal yang sama dilakukan proses analisis terhadap hasil pekerjaan dari subyek 2. Berikut ini hasil pekerjaan dari subyek 2. 


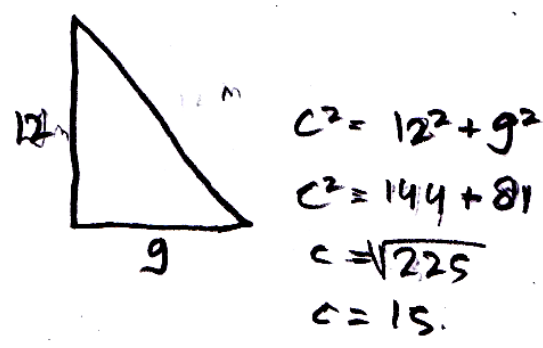

\section{Gambar 5. Hasil Pekerjaan dari Subyek 2}

Subyek 2 telah mampu mereduksi apa yang ditemukannya dalam proses diskusi untuk menyelesaikan permasalahan dalam soal. Tetapi subyek 2 tidak mengkonstruksi, menginventaris apa yang diketahui dalam soal untuk diselesaikan permasalahannya. Dalam hal ini subyek 2 telah mempunyai inisiatif untuk mengilustrasikan permasalahan dalam bentuk gambar, walaupun belum jelas apa yang dimaksudkan dalam gambar. Karena subyek 2 tidak menamai gambar yang telah dibuatnya. Sehingga orang lain tidak mengerti apa yang dimaksud dalam gambar.

Dari gambar 5 juga tampak bahwa subyek 2 langsung pada perhitungan. Tiba-tiba langsung memunculkan angka, tanpa diketahui orang lain yang membaca pekerjaannya, angka-angka itu merepresentasikan apa dan huruf yang ditulis itu merepresentasikan apa. Subyek 2 juga belum sampai pada tahap pemecahan masalah, menyimpulkan solusi dari permasalahan yang diberikan.

Dari proses analisis pekerjaan subyek 1 dan subyek 2, dapat disajikan dalam Tabel 1.

\section{Tabel 1. Analisis Hasil Pekerjaan Subyek}

\begin{tabular}{lcrlrr}
\hline \multicolumn{2}{c}{ Hasil dari Pekerjaan Subyek 1 } & \multicolumn{3}{c}{ Hasil dari Pekerjaan Subyek 2 } \\
\hline Mengerjakan langsung pada & Tidak mengidentifikasi & hal-hal \\
perhitungan tanpa menuliskan hal- & yang diketahui, mencari hubungan \\
hal yang diketahui dalam soal, & dan & memodelkan & dalam \\
mencari & hubungan & dan & matematikar & Peneliti & menduga \\
memodelkan & dalam & bentuk & langsung mementingkan pada hasil. \\
matematika. & & & Mampu & mereduksi & proses \\
\hline
\end{tabular}


14 | Mulyatna: Proses Pembentukan Konsep dalam Menemukan Kembali Teorema Pythagoras...

\begin{tabular}{lll}
\hline $\begin{array}{l}\text { Mengerjakan sebatas menirukan } \\
\text { berdasarkan pengalaman saat }\end{array}$ & $\begin{array}{l}\text { penemuan kembali } \\
\text { Pythagoras }\end{array}$ & $\begin{array}{r}\text { Teorema } \\
\text { sehingga }\end{array}$ \\
membuktikan/menemukan & perhitungannya langsung memakai \\
kembali Teorema Pythagoras. & rumus yang telah ditemukan. \\
Mengalami miskonsepsi, adanya & Telah mempunyai inisiatif untuk \\
angka yang dihilangkan tanpa & merepresentasikan masalah ke \\
proses hitung. & dalam bentuk gambar walaupun \\
Mengalami miskonsepsi dalam & belum jelas. \\
perhitungan, yaitu melakukan & \\
perlakuan operasi akar hanya pada & \\
satu ruas dalam sistem persamaan. &
\end{tabular}

\section{Analisis Hasil Wawancara}

Wawancara digunakan untuk lebih memperdalam data yang diperoleh. Di samping itu wawancara juga dimaksudkan untuk menggali informasi lain yang dapat mendukung temuan data pada analisis hasil pekerjaan subyek. Wawancara dapat berperan juga sebagai klarifikasi. Script wawancara disajikan dengan penulisan $\mathrm{P}$ sebagai peneliti, S1 sebagai subyek 1 dan S2 sebagai subyek 2.

Informasi awal yang diperoleh, subyek 1 baru mengenal pendekatan PMRI dan sebelumnya belum pernah melaksanakan pembelajaran dengan pendekatan PMRI. Pendekatan PMRI mendapat respon yang baik dari subyek 1 .

Subyek 1 mengalami miskonsepsi dalam menafsirkan teorema. Menurut subyek 1, antara teorema dan rumus adalah sama, hal ini berdasarkan script wawancara:

P : "Menurut Adik, apa to yang dimaksud Teorema Pythagoras?"

S1 : "Ya itu Pak, $a^{2}+b^{2}=c^{2}$."

$\mathrm{P}$ : "Lha kalau Rumus Pythagoras?"

S1 : "Ya sama."

Miskonsepsi subyek 1 juga berkaitan dalam mengidentifikasi sisi miring (hipotenusa) dalam segitiga siku-siku. Hal ini berakibat miskonsepsi juga dalam penamaan sisi-sisi dalam segitiga. Identifikasi 
hipotenusa menjadi sisi yang miring menjadi salah apabila posisi hipotenusa dilukiskan sebagai alas (horisontal) maupun dilukiskan vertikal. Berikut script wawancara yang menunjukkan keadaan tersebut:

$\mathrm{P} \quad$ : “ $a, b, c$ itu apa Dek?"

S1 : "Ya sisi-sisi segitiga siku-siku."

$\mathrm{P}$ : "Cara menamainya gimana?"

S1 : “ Ya pokoke ki yang sisi miringnya $c$, yang lainnya tinggal dikasih aja nama $b$ dan $a . "$

$\mathrm{P}$ : "Tahu sisi miringnya? Gimana Adik membedakan sisi miring dengan sisi yang lainnya?"

S1 : "Sisi yang miring Pak."

Berdasarkan hasil pekerjaan subyek 1, dilakukan klarifikasi dan diperolehlah script wawancara:

$\mathrm{P}$ : “ Ni hasil pekerjaanmu (sambil nunjukkan lembar jawab), ni angka 216-nya kok bisa hilang?"

S1 : "Itu ki supaya menjadi bentuk kuadrat ditambah kuadrat, sesuai rumusnya, jadi dihilangin."

Script wawancara menunjukkan subyek 1 mengalami miskonsepsi dalam perhitungan sebuah sistem persamaan. Miskonsepsi ini berkaitan dengan pemberian operasi hitung pada sistem persamaan harus kedua ruas dikenai proses yang sama. Terlihat bahwa adanya angka hilang, dan pengenaan operasi kuadrat dan akar kuadrat hanya pada satu ruas saja.

Dalam mengerjakan soal, subyek 1 orientasinya langsung pada perhitungan dengan tertuju pada rumus yang digunakan. Script wawancara yang menunjukkan hal tersebut:

$\mathrm{P}$ : " Sekarang Bapak ingin tahu tentang pekerjaanmu ya Dik, kalau Adik mengerjakan soal, apa strategi Adik untuk menyelesaikannya?"

S1 : "Ya langsung mikirin rumus apa yang bisa digunain to Pak."

$\mathrm{P}$ : "Trus kalau rumusnya lupa gimana coba?"

S1 : "Ya gak bisa dikerjain to Pak."

Subyek 1 baru menangkap informasi dengan apa adanya. Berkaitan dengan konsep penerapan Teorema Pythagoras, saat ditanyakan kalau 
16 | Mulyatna: Proses Pembentukan Konsep dalam Menemukan Kembali Teorema Pythagoras...

diterapkan dalam segitiga sama kaki bisa atau tidak, dan subyek 1 menjawab tidak. Padahal kalau subyek 1 bisa menggali lebih dalam, ada kemungkinan bahwa segitiga sama kaki juga merupakan segitiga sikusiku pada kasus tertentu.

Hasil wawancara juga menunjukkan Subyek 2 juga baru mengenal pendekatan PMRI dan belum pernah mengalami pembelajaran dengan pendekatan PMRI sebelum-sebelumnya. Subyek 2 merasa lebih nyaman pembelajaran dengan implementasi Pendekatan PMRI.

Subyek 2 sudah mampu untuk membedakan antara teorema dan rumus, walaupun belum begitu jelas. Hal ini ditunjukkan dalam script wawancara:

P : "Menurut Adik, apa to yang dimaksud Teorema Pythagoras?"

S2 : "Hubungan sisi-sisi dalam segitiga siku-siku Pak."

P : "Maksudnya hubungan?"

S2 : "Ya kalau ada segitiga siku-siku, berarti sisi yang miring itu dikuadratkan, hasilnya sama besar dengan sisi yang lain dikuadratkan terus dijumlah Pak."

P : "Lha kalau Rumus Pythagoras?"

$\mathrm{S} 2: " a^{2}+b^{2}=c^{2}$."

Miskonsepsi subyek 2 juga berkaitan dalam mengidentifikasi sisi miring (hipotenusa) dalam segitiga siku-siku. Sehingga berakibat juga miskonsepsi dalam penamaan sisi-sisi dalam segitiga. Berikut ini script wawancaranya:

$\mathrm{P} \quad$ : " $a, b, c$ itu apa Dek?"

$\mathrm{S} 2$ : " $c$-nya itu sisi miring, $b, a$ berarti yang lainnya."

$\mathrm{P} \quad$ : "Tahu $a, b, c$ ?"

S2 : "Ya yang sisi miring $c$, yang lain $b$ dan $a . "$

$\mathrm{P} \quad$ : "Tahu sisi miringnya?

S2 : "Yang miring Pak, dan biasanya lebih besar."

Subyek 2 sudah mampu untuk mengolah informasi lebih mendalam. Hal ini diketahui dari hasil wawancara yang menyatakan bahwa subyek 2 mampu mengidentifikasi segitiga siku-siku yang sekaligus segitiga sama kaki. Berikut script wawancaranya: 
P : “ Oh...Lalu bisa menerapkan Rumus Pythagoras dalam sebuah soal itu kapan?"

S2 : "Pada segitiga siku-siku Pak."

P : "Kalau segitiga sama kaki tidak bisa?"

S2 : "Kalau siku-siku, bisa Pak."

Dalam mengerjakan soal, subyek 2 sudah ada inisiatif untuk mengkonstruksikannya ke dalam informasi baru yang lebih jelas walaupun belum nampak memberikan penamaan yang dapat memperjelas informasi. Subyek 2 juga masih mengerjakan soal dengan orientasi rumus yang digunakan. Berikut script wawancaranya:

P : " Saya udah melihat hasil dari pekerjaanmu Dik, kalau Adik mengerjakan soal langkah-langkah untuk menyelesaikannya gimana?"

S2 : “ Kalau soal cerita, kalau bisa digambar, saya gambar, kan keliatan yang diketahui apa aja. Lalu tak pikirkan rumus yang digunakan"

Kelemahan dari subyek 2 adalah perkerjaan yang hanya orientasi pada hasil akhir, belum pada arah untuk menjawab dari solusi yang diinginkan. Berikut script wawancaranya:

P : " Lha kalau orang lain baca pekerjaan kamu, apakah orang lain tahu apa yang dimaksudkan? Trus kalau rumusnya lupa gimana coba?"

S2 : "Ya kan yang penting angka-angka yang dibutuhkan Pak, kelamaan kalau ditulis kata-kata. Ya gak tak kerjain Pak."

P : "Menurut kamu, dari hasil pekerjaanmu, mana yang kamu sebut solusi?"

S2 : "15 Pak."

\section{Pembahasan}

Data yang diperoleh berdasarkan observasi implementasi pendekatan PMRI, hasil pekerjaan siswa dan hasil wawancara kemudian dianalisis untuk memperoleh data akhir yang dapat dijadikan hasil dari penelitian ini. 
18 | Mulyatna: Proses Pembentukan Konsep dalam Menemukan Kembali Teorema Pythagoras...

Proses pembentukan konsep dalam menemukan kembali Teorema Pythagoras dengan pendekatan PMRI dapat berjalan dengan cukup baik walaupun siswa belum pernah memperoleh dalam pembelajaran sebelumnya. Termasuk juga kedua subyek dalam peneilitian ini. Indikatornya dapat tercermin dari proses pembelajaran, siswa memberikan respon yang positif, adanya perubahan karakter dalam mengemukakan gagasan, mengkonstruksi pengetahuan lama dan memperoleh pengetahuan baru. Siswa tidak hanya sekedar menunggu, tetapi berusaha untuk mendapatkan pengetahuan barunya. Sehingga dalam memperoleh pengetahuan baru, masing-masing siswa mempunyai pendapat yang beragam.

Kedua subyek belum mampu mengkonstruksikan dengan baik permasalahan yang diberikan berupa soal. Kedua subyek belum memodelkan matematika dengan baik. Orientasi yang dituju subyek langsung pada perhitungan, rumus yang digunakan dan hasil akhir dari perhitungan. Sehingga solusi dari permasalahan belum terjawab oleh subyek.

Adanya perbedaan pada kedua subyek dalam mengolah informasi. Subyek 1 mengolah informasi secara mentah. Hasil dari penemuan konsep dengan pengetahuannya digunakan dalam memecahkan masalah dengan jalan yang sama, belum mampu mereduksi data. Untuk yang subyek 2, sudah mampu mengolah informasi yang diperolah dan menafsirkan masalah secara lebih jauh.

Kedua subyek masih mengalami miskonsepsi, baik itu pengetahuan yang telah dimiliki maupun pengetahuan yang baru didapat. Subyek 1 masih mengalami miskonsepsi dalam operasi hitung pada sistem persamaan yaitu operasi hitung pada kedua ruas, yang dilakukan hanya pada satu ruas saja. Miskonsepsi yang dialami subyek 1 juga dalam membedakan antara teorema dan rumus. Sedangkan kedua subyek mengalami miskonsepsi dalam mendeskripsikan sisi miring (hipotenusa) dan pemberian nama sisi-sisi dari segitiga siku-siku.

Berdasarkan pembahasan analisis ternyata implementasi pendekatan PMRI ini masih mengalami kendala dan permasalahan yang ditemukan di 
dalam pembelajaran, untuk itu solusi yang ditawarkan peneliti adalah pembiasaan pembelajaran dengan pendekatan PMRI. Alasannya pada pembelajaran yang dilakukan peneliti, pendekatan PMRI mendapat respon yang positif, walaupun baru pertama kalinya. Pertimbangannya, siswa mengalami perubahan karakter yang menunjukkan adanya kemauan dan keberanian dalam mengeluarkan pengetahuaannya. Bisa diartikan bahwa mengarahkan suasana pembelajaran yang berorientasi pada pemecahan masalah dengan pembelajaran yang tepat. Hal ini mengacu pada penelitiannya Saefudin (2012) bahwa dalam pemecahan masalah matematika, diperlukan pemikiran dan gagasan yang kreatif dalam membuat (merumuskan) dan menyelesaikan model matematika serta menafsirkan solusi dari suatu masalah matematika. Pemikiran dan gagasan yang kreatif tersebut akan muncul dan berkembang jika proses pembelajaran matematika di dalam kelas menggunakan pendekatan pembelajaran yang tepat.

Perlu adanya variasi pemberian soal sehingga soal tidak hanya berorientasi pada penggunaan rumus tetapi siswa diarahkan pada proses berpikir untuk mengolah informasi dalam soal. Dalam hal ini peneliti mengarahkan soal yang diberikan hendaknya yang ada kaitannya dengan kehidupan sehari-hari atau soal yang real. Pendekatan PMRI menjadi salah satu alternatif pendekatan yang membuat suasana pembelajaran menjadi pengalaman keseharian siswa. Dalam Arsaythamby, V. \& Zubainur (2014) dijelaskan, "IRME (Indonesian Realistic Maths Education) stresses that teaching and learning aids should be related to students' daily lives and experiences." Dengan kata lain, pendekatan PMRI lebih memfokuskan alat bantu pengajaran dan pembelajaran harus terkait dengan kehidupan dan pengalaman sehari-hari siswa.

Guru dalam proses pembelajaran tidak langsung memberikan formula-formula siap pakai dan rumus-rumus, tetapi membangun pengetahuan dan konsep siswa dengan pertanyaan-pertanyaan yang merangsang siswa untuk menggali pengetahuannya. Pembelajaran matematika akan lebih efektif jika siswa dapat bekerja untuk memproses dan mengubah informasi secara aktif. Hal ini merujuk pendapatnya 
20 | Mulyatna: Proses Pembentukan Konsep dalam Menemukan Kembali Teorema Pythagoras...

Laurens (2018), Mathematics learning would be more effective if students are able to work to process and change information actively.

Miskonsepsi yang dialami siswa dapat diberikan solusi dengan memberikan kesempatan diskusi dan mengarahkan antara konsep dan bukan konsep, dengan melibatkan siswa. Keterlibatan siswa dalam pembentukan konsep melalui ruang diskusi diharapkan dapat mengembangkan kemampuan berpikir kreatif. Sekolah Menengah Pertama (SMP) yang merupakan bagian dari jenjang pendidikan dasar, merupakan kelanjutan dari Sekolah Dasar (SD) yang seharusnya siswasiswinya terlatih untuk berpikir kritis. Hal ini juga diungkapkan oleh Amir dan Wardana (2017), pendidikan Sekolah Dasar merupakan pondasi utama untuk menanamkan sekaligus mengembangkan kemampuan berpikir kreatif siswa, oleh sebab itu seharusnya sekolah-sekolah di Sekolah Dasar (SD) harus menyiapkan dan mencetak siswa agar menjadi pemikir kreatif yang siap bersaing pada jenjang pendidikan berikutnya serta memiliki bekal yang dapat digunakan bagi kehidupannya kelak.

\section{SIMPULAN}

Berdasarkan hasil penelitian dan pembahasan, dapat diperoleh kesimpulan bahwa kedua subyek belum mampu mengkonstruksikan dengan baik permasalahan yang diberikan berupa soal menjadi memodelkan matematika dengan baik, sehingga solusi dari permasalahan belum terjawab oleh subyek. Adanya perbedaan pada kedua subyek dalam mengolah informasi. Subyek 1 mengolah informasi secara mentah. Hasil dari penemuan konsep dengan pengetahuannya digunakan dalam memecahkan masalah dengan jalan yang sama, belum mampu mereduksi data. Untuk yang subyek 2, sudah mampu mengolah informasi yang diperoleh dan menafsirkan masalah secara lebih jauh. Kedua subyek masih mengalami miskonsepsi, baik itu pengetahuan yang telah dimiliki maupun pengetahuan yang baru didapat. Miskonsepsi dalam operasi hitung pada sistem persamaan yaitu operasi hitung pada kedua ruas, yang dilakukan hanya pada satu ruas saja, miskonsepsi dalam mendeskripsikan 
hipotenusa sebagai sisi yang miring dan pemberian nama sisi-sisi dari segitiga siku-siku dengan mencirikan sisi yang miring sebagai $c$.

\section{DAFTAR PUSTAKA}

Amir, M.F. dan Wardana, M.D.K. (2017). Pengembangan Domino

Pecahan Berbasis Open Ended untuk Meningkatkan Kemampuan Berpikir Kreatif Siswa SD. AKSIOMA: Jurnal Program Studi Pendidikan Matematika, 6(2), 178-188. Retrieved from http://ojs.fkip.ummetro.ac.id/index.php/matematika/article/view/10 15

Arsaythamby, V., \& Zubainur, C. M. (2014). How a realistic mathematics educational approach affect students' activities in primary schools? In Procedia-Social and Behavioral Sciences, WCPCG, 2014, 159, 309-313. Retrieved from http://doi.org/10.1016/j.sbspro.2014.12.378

Habsah, F. (2017). Developing Teaching Material Based on Realistic Mathematics Andoriented to the Mathematical Reasoning and Mathematical Communication. Jurnal Riset Pendidikan Matematika, 4 (1), 43-55. Retrieved from http://dx.doi.org/10.21831/jrpm.v4i1.10199

Hamza, K.M., dan Wickman, P. (2007). Describing and Analyzing Learning in Action: An Empirical Study of The Importance of Misconceptions in Learning Science. Science Education, 92(1), 141 - 164. Retrieved from https://doi.org/10.1002/sce.20233

Kirom, A. (2017). Peran Guru dan Peserta Didik dalam Proses Pembelajaran Berbasis Multikultural. Al-Murabbi: Jurnal Pendidikan Agama Islam, 3(1), 69-80. Retrieved from http://jurnal.yudharta.ac.id/v2/index.php/pai/article/download/893/7 62

Laurens, T., Batlolona, F. A., Batlolona, J. R., \& Leasa, M. (2018). How Does Realistic Mathematics Education (RME) Improve Students' Mathematics Cognitive Achievement? Eurasia Journal of 
22 | Mulyatna: Proses Pembentukan Konsep dalam Menemukan Kembali Teorema Pythagoras...

Mathematics, Science and Technology Education, 14(2), 569-578. Retrieved from http://www.ejmste.com/How-Does-RealisticMathematics-Education-RME-Improve-Students-Mathematics-

Cognitive, 76959,0,2.html

Novak, J.D. (2002). Meaningful Learning: The Essential Factor for Conceptual Change in Limited or Inappropriate Propositional Hierarchies Leading to Empowerment of Learners. Science Education, 86(4), 549-571. Retrieved from https://onlinelibrary.wiley.com/doi/abs/10.1002/sce.10032

Saefudin, A.A. (2012). Pengembangan Kemampuan Berpikir Kreatif Siswa dalam Pembelajaran Matematika dengan Pendekatan Pendidikan Matematika Realistik Indonesia (PMRI). Al-Bidayah, 4(1), 37-48. Retrieved from https://jurnal.albidayah.id/index.php/home/article/view/10

Tekkaya, C. (2002). Misconceptions as Barrier to Understanding Biology. Hacettepe Oniversitesi Egitim Fakilltesi Dergisi. 23, 259-266. Retrieved from http://www.efdergi.hacettepe.edu.tr/yonetim/icerik/makaleler/971 published.pdf

Wardono, Waluya, S. B, Mariani S., \& S Candra D. (2016). Mathematics Literacy on Problem Based Learning with Indonesian Realistic Mathematics Education Approach Assisted E-Learning Edmodo. Journal of Physics: Conference Series, 693. Retrieved from https://iopscience.iop.org/article/10.1088/1742-6596/693/1/012014 